\title{
THE FORMING OF CASTELLUM-TYPE CASTLES AND FOUR-UNIT BUILDING COMPLEXES WITH CHAPELS IN SECULAR POWER CENTRES OF COURLAND AND THE STATE OF THE TEUTONIC ORDER
}

\author{
Silvija Ozola \\ Riga Technical University, Latvia
}

\begin{abstract}
In the noble families houses, a sacral room or a separate volume made for relics' storage or prayers started to call the chapel (German: Kapelle, Latin: capella). The name for this building type was borrowed from the Latin words cappa, capa. The knights for implementation of its policy on conquered lands inhabited by the Balts founded economically independent castles of stone that included chapels. According to regulations of castellum's planning, the chapel had to be situated on the east side of the structure. In Livonia and the State of the Teutonic Order, the location of castles and cult buildings influenced layouts of town centres. Research goal: analysis the impact of cult buildings on layouts and spatial structures of castles and fortified centres to determine common and different characteristics in Livonia and the State of the Teutonic Order. Research problem: the influence of sacred buildings' location on layouts of castles, built by the Teutonic Order. has not well researched. Research novelty: structures of the Teutonic Order's fortresses are studied in the context of Italian architecture. Research methods: studies of urban planning cartographic materials, archive documents, projects, published literature and inspection of buildings in nature.
\end{abstract}

Keywords: castle, chapel, Livonia, medieval town, the State of the Teutonic Order.

\section{Introduction}

The Roman Emperor (284-305) Gaius Aurelius Valerius Diocletianus (244-311) carried out territorial reforms (293) to preserve the Empire. Not far from his native place Salona (now Split, Croatia) on the Adriatic Seacoast, he built the rectangular military urban complex surrounded by high defensive walls with fifteen towers - the Diocletian's Palace (Italian: Palazzo di Diocleziano; 295-305) (Fig. 1) called "castellum", which was a diminutive shape for a strong fortress "castra" or "castrum". The complex which southern façade facing the sea had a large hall with a dome-covered vestibule, the Emperor's mausoleum, Jupiter, Cybele and Venus temples. Emperor's private rooms overlooked a beautiful sea view. On the Adriatic Seacoast, the Rialto - the fisheries settlement developed ( $5^{\text {th }}-9^{\text {th }}$ cent.) by merchants became the Venetian Duchy's centre at the 
Grand Canal's estuary into the Venetian Lagoon (Italian: Laguna Veneta). In Western Europe during the $5^{\text {th }}-10^{\text {th }}$ centuries, the feudal order formed under the influence of military conflicts. Rulers built castles-fortresses for residences. In Venice city got after 584 over the Ravenna Archbishoprics, a castellum for governmental institutions, ruler's apartments, courtrooms, a prison and stables was built, using for example the Diocletian's Palace included in the Republic of Venice (Italian: Repubblica di Venezia; 697-1797).

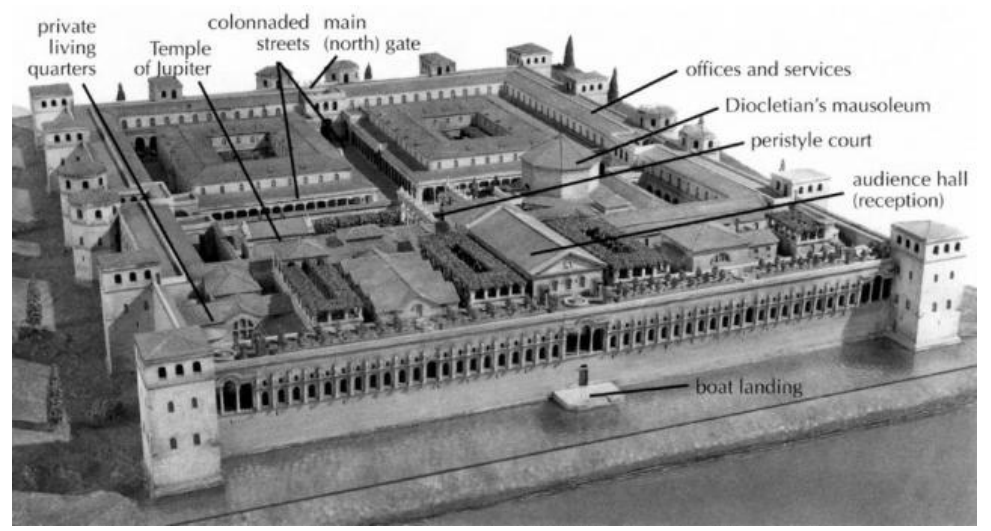

Figure 1 The reconstruction of Diocletian's Palace complex in Split (online 13.01.2018, http://2.bp.blogspot.com/-8SdQCZupsDo/UeIrBgVz4cI/ AAAAAAAATSU/b0Jz2k7-LJw/s1600/1a2+Diocletian\%2527s+Palace.JPG)
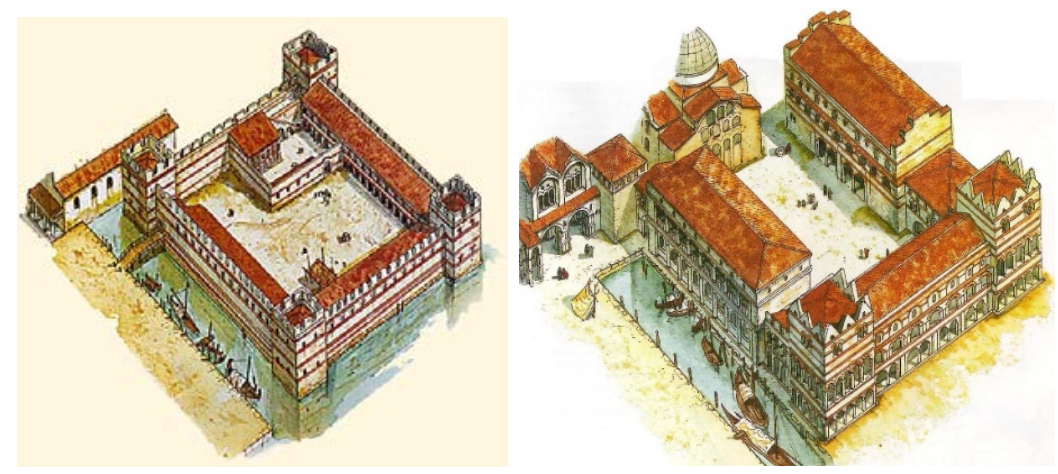

Figure 2 The castellum of the Doge's Palace $\left(1^{\text {th }}-11^{\text {th }}\right.$ cent.) in Venice (online 24.06.2017, http://palazzoducale.visitmuve.it/wp-content/uploads/2011/05/Castello-Palazzo-Ducale.jpg)

Figure 3 The castellum of Venice Doge Ziani's Palace with three big buildings (online 24.06.2017, http://imiglioriannidellac.blogspot.com/2012/01/venezia-palazzo-ducale.html)

The first leader of the Republic of Venice, Dodge (Italian: Doxe, Latin: Dux - power, leadership) Paolo Lucio Anafesto built the castellum of the Dodge's Palace (German: Dogenpalast, Italian: Castello Palazzo Ducale; around 700) with strong walls and massive corner towers. The first Emperor (800-814) of the Holy Roman Empire (Latin: Imperatores Romani Sacri, German: Römisch-deutscher 
Kaiser) Carolus Magnus (German: Karl der Große) at the mouth of the Elba River erected a stone castle (808) for administration and waterway protection against Slavic invasions. In 810, the first church in Hamburg was consecrated. St. MarienDom (German: Hamburger Dom; around 811) was built to establish the Bishopric centre, and next to it - the Bishop's residence (834). The southern suburbs of Carolus Magnus possessions was Northern Italy where cities sought independence. Venice city-state $\left(9^{\text {th }}-12^{\text {th }}\right.$ cent.) became an important trade centre between Western Europe, the Middle East and Asia. Using the Diocletian's Palace as a sapmle, Dodge (810-827) Angelo Partecipazio rebuilt the Doge's Palace, including in it three big blocks (Fig. 2): one directed towards il rio del Palazzo, the second - towards the water area Bacino di San Marco, but the third - towards Piazzetta (Fig. 3). A strong gate provided the palace's main entrance, that now is the portal of Porta della Carta. On the side of St. Mark's Square (Italian: Piazza San Marco; 800-1100) construction of the residence (810, destroyed in the $10^{\text {th }}$ century) began, and in 827 it was continued by Dodge (827-829) Giustiniano Partecipazio. He started construction of St. Mark's Basilica (Italian: Basilica di San Marco; 828-832) for the Apostle Mark's relics, which on 31 January 829 were brought from Alexandria to Venice. His brother, Doge (829-836) Giovanni I Parteciapazio completed this construction. Doge (887-911) Pietro Tribuno built a freestanding watchtower-lighthouse ( $9^{\text {th }}$ cent.) on St. Mark's Square. Venice was fortified. Later, a bell was placed in the tower (Italian: Campanile di San Marco obtained the current appearance in 1514). During the coup in 976, fire caused damage to the basilica and partly destroyed the Doge's Palace, which restored until the late $10^{\text {th }}$ century, not built again. During the renovation opened the old masonry wall quite possibly a part of the basilica.

In the Dodge's Palace yard's north part, Dodge (1041-1071) Domenico I Contarini on the place of damaged basilica built St. Mark's Cathedral (10631071, consecrated in 1073) using for a sample the Greek Eastern Orthodox Church Apostleion or the Church of the Holy Apostles (Italian: chiesa dei Santi Apostoli; around 330, destroyed in 1461) known as the Imperial Polyándreion (cemetery) in Constantinople (now Stambul). In the centre of the cathedral obtained a Greek cross layout, the burial of the apostle's relic placed under a big dome. Four smaller ones located at the ends. St. Mark's Cathedral (Fig. 5), considered as the Dodge's Palace Chapel till 1807, was included in building perimeter similar to St. Maria Latina Church (Fig. 4) on the north side of the Benedictine monastery's (before 1071) yard (Latin: claustrum, French: cloître) in Jerusalem. Construction of the cathedral finished in 1094. During the Dodge's Palace rebuilding, Dodge (11721178) Sebastiano Ziani envisaged one house for administration, but another for legal affairs. 
Ozola, 2020. The Forming of Castellum-Type Castles and Four-Unit Building Complexes with Chapels in Secular Power Centres of Courland and the State of the Teutonic Order
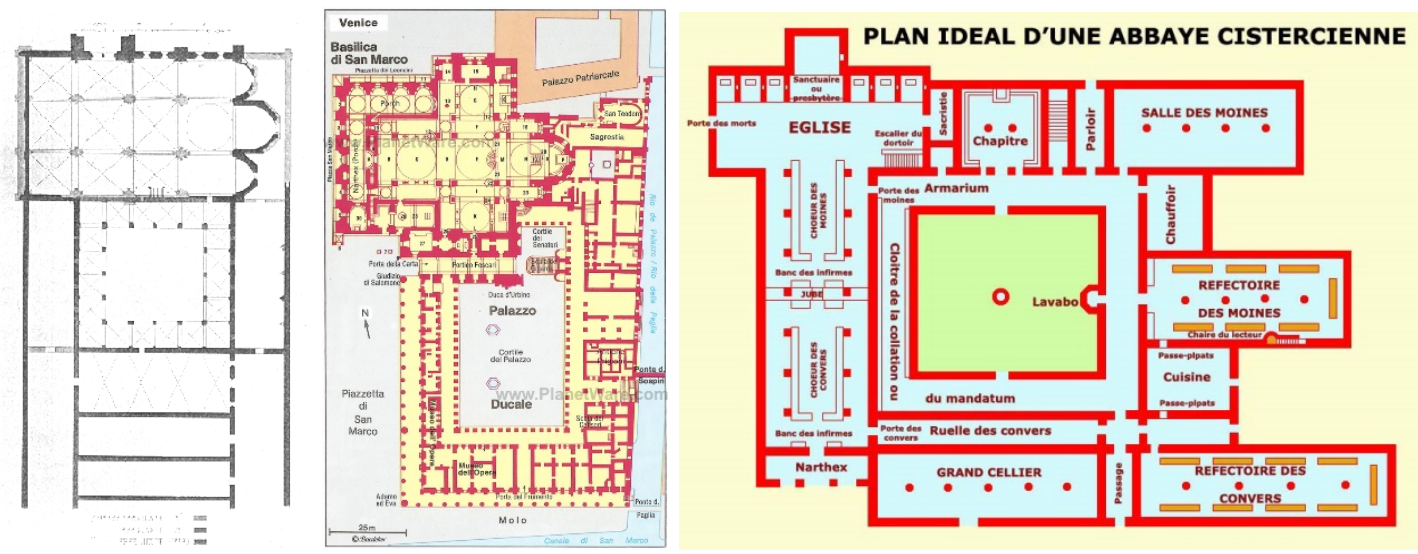

Figure 4 The first floor plan of St. Maria Latina Benedictine monastery complex in Jerusalem (online 19.06.2017, http://blessed-gerard.org/images/stmarlat.gif)

Figure 5 Wagner \& Debes. The plan of St. Mark's Cathedral (1063-1071) and the Doge's

Palace complex in Venice. 1899 (online 19.06.2017,

http://www.planetware.com/i/map/I/venice-basilica-di-san-marco-map.jpg)

Figure 6 Brun Georges. The Cistercian monastery idealplan. 2010 (online 03.05.2018, http://www.crdp-strasbourg.fr/data/hist-arts/art_roman/images/big-cistercien_abbaye.jpg)

Benedictine monks who criticized crave for luxury and unwillingness to do hard work, joined in a group and formed the Cistercian Order (Latin: Ordo Cisterciensis). The first Cistercian monastery (French: Abbaye Notre-Dame de Cîteaux, Latin: Cistercium) called the New Monastery (Latin: Novum Monasterium) was founded (1098) in French Region Côte d'Or and sustained with farming and a brewery. Applying as a sample the Benedictine monastery basilica, the Cistercians in 1135 started to build the Basilica of Clairvaux Abbey (Latin: Clara Vallis). However, Abbot of Clairvaux (1115-1128) Bernardus criticized too long and wide edifice. Monks of Cluny Abbey criticized introduced requirements. Bernardus, having borrowed the idea form ancient Greek homes with rooms placed around the peristyle (Latin: peristylium) or an open square courtyard surrounded by the portico, developed a functional scheme (Fig. 6) for construction of Cistercian monastery complexes. The church located in the north, cells (Latin: cella) placed in the west, dinning-rooms (German: Remter, Latin: refectorium) - in the south, a library, sacristy, other rooms - in the east (Ozola, 2018). Pope (1145-1153) Eugenius III issued (1145) the bull to organize the second Crusade (1147-1149). Bernardus Claraevallensis invited the knights to become missionaries and preach Christianity in pagan lands (Spekke, 2008, 113). In Jerusalem, brothers-knights (Latin: fratres) rebuilt the Church of the Anastasis, solemnly consecrated it on 15 July 1149, and ruled the most important shrine of Christians until 4 July 1187, when lost the city: all churches except the Church of the Anastasis converted into mosques. 
During the third Crusade (1189-1192), monks, merchants and the knights from Lübeck and Bremen arrived in Palestine. On 1 September 1190 they made a hospital to treat injured outside walls of port-city Acre, know to locals as Akko (also Akers, Ptolemais, Antioch, or Antiochenes, Latin: Ace). On 6 February 1191 Pope (1187-1191) Clement III confirmed "Brotherhood of St. Mary's Teutones in Jerusalem" (Latin: Fratrum Theutonicorum ecclesiae S. Mariae Hiersolymitanae). After the invasion of Akko in 12 July 1191, bothers-knights moved the hospital into the city. On 21 December 1196 Pope (1191-1198) Caelestinus III took the Germans' St. Mary's Hospital of Jerusalem (Latin: Hospitele sancte Marie Theutonicorum Jerosolimitanum) under his protection and allowed brothers-knights to elect their leader or Master (Latin: magister, German: Meister) (Šterns, 2002, 32-33). On 19 February 1199 Pope (1198-1216) Innocentius III approved the name "Brothers and Sisters of the German House of St. Mary in Jerusalem" (Latin: Ordo domus Sanctae Mariae Teutonicorum in Jerusalem, German: Brüder und Schwestern vom Deutschen Haus Sankt Mariens in Jerusalem, also Deutschherrenorden or Deutschritterorden, abbreviated: Deutsche Orden; 1198-1525). The Teutonic Order's Master (Deutschmeister des Deutschen Ordens, 1219-1230, Landmeister von Preußen des Deutschen Ordens 1229-1239) Hermann Balk, Bishop of Breslau Thomas I (?-1268) and Magdeburg citizen Heinrich der Bärtige (Heinrich I. von Schlesien, Heinrich I. von Polen, Polish: Henryk I Brodaty; 1163-1238) signed an agreement for the establishment of towns in the State of the Teutonic Order (Latin: Civitas Ordinis Theutonici, German: Staat des Deutschen Ordens; 1230-1525) (Fig. 7). The knights started to build financially independent castles for Commandry and Vogtei centres.

Prominent Latvian historian, Dr. Ph. Professor emeritus at Muhlenberg College (USA) Indrikis Šterns (1918-2005) divided the Crusades in Livonia into three thirty-year periods. The first period ended with the establishment of the sovereign Livonia state and the Episcopate of Bishop Albert, the subjugation of Latgalia (now Eastern Latvia) and the loss of the Cours' independence in 1230 (Šterns, 2002, 173). The territorial division of Livonia into castle-regions (Latin: castellatura, Scandinavian: borchsokinge) was preserved, but under the Catholic Churche's subjugation, castle-regions gradually replaced by parishes (Old German: kerszpel) changing borders in compliance with the new administrative system (Šterns, 1997, 105). 
Ozola, 2020. The Forming of Castellum-Type Castles and Four-Unit Building Complexes with Chapels in Secular Power Centres of Courland and the State of the Teutonic Order

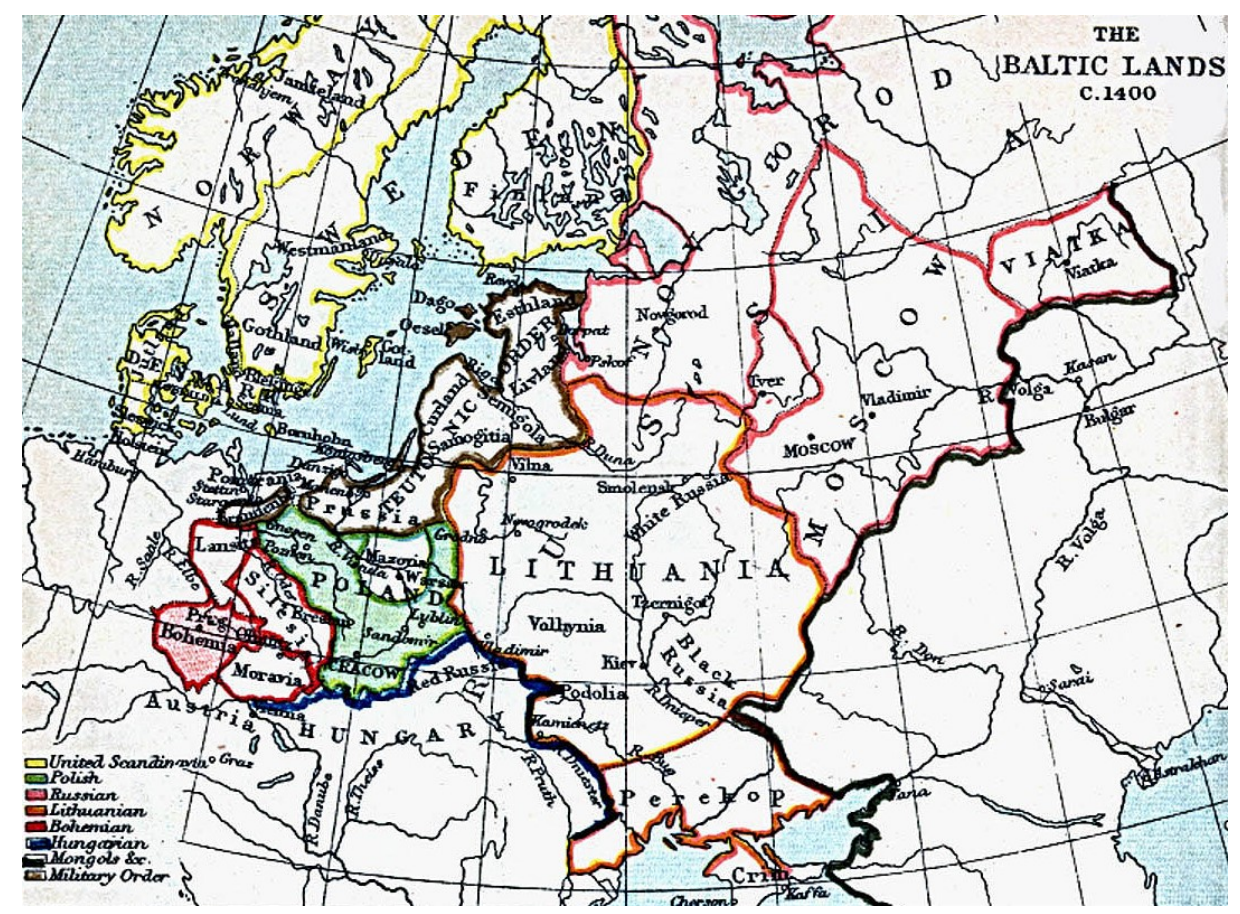

Figure 7 John Bagnell Bury (1861-1927). Map of the State of the Teutonic Order included in 1400 the Balts and the Prussian lands. 1903

(https://legacy.lib.utexas.edu/maps/historical/baltics_1400.jpg)

Previous studies on the Teutonic Order's history and construction of castles in the State of the Teutonic Order and the Livonian State: Priest Hermann of Wartberge (died ca. 1380), staying in Livonia, used previous chronicles as the Livonian Rhymed Chronicle and the Livonian Chronicle of Henry, archival documents and personal experiences and in "Hermanni de Wartberge Chronicon Livoniae” (Vartberge, 2005) covered the Livonian Crusades’ history from 1196 up to 1378, but Priest Peter of Dusburg (Latin: Petrus de Dusburg; the second half of the $13^{\text {th }}$ century-after 1326) wrote “Chronik des Preußenlandes" /The Chronicle of the Prussian Land/ (Latin: Chronicon Terrae Prussiae; 1326) (Dusburg). Houseowner, merchant Jürgen Helmes (also Georg Helm, Helms, Helmer; around 1603-after 1655) from Riga since 1628 began to write "Chronicon Lyvoniae" about the period from 1158 to 1648 - in Livonian historiography the only Chronicle supplemented by drawings. Layouts of castles with courtyards and façades by towers were seen from a high perspective. Historian, librarian, regional researcher Aleksandrs Jansons (1916-1991) and engineer Gunārs Erdmanis (1927-1990) infered in a study „Helmsa hronikas zìmējumu analīze" /Analysis of Drawings of Helm's Chronicle/ published in 1988, that symbolic drawings of castles do not represent true buildings. The Holy Roman Emperor (1658-1705) Leopold I (full name: Leopold Ignaz Joseph Balthasar Felician, born Habsburg) in 1661 traveled from Vienna to Moscow. 
Artist Johann Rudolf Storno (also Storn) from Switzerland traveled along with the delegation and created drawings of castles in order to complement travel notes. Artist August Georg Wilhelm Pezold (1794-1859) produced lithographs for illustrations of delegation chief Augustin Freiherr von Mayerberg's (also Meyerberg; 1612-1688) report. Friedrich von Adelung (1768-1843) published drawings in two volumes of the Meierberg's Album (1827). Konrector at Riga Lyceum (Latin: Schola Carolina), historian Johann Gottfried Arndt (1713-1767) in accordance with written historical sources created (1753) the first scientifically compiled list of Livonian castles. Painter, Baron Carl Johann Emanuel von Ungern-Sternberg's (1773-1830) drew (1810-1829) Livonian castles, churches and their plans. At the end of the $18^{\text {th }}$ century Konrector at the Riga Imperial Lyceum, painter Johann Christoph Brotze (1742-1823) began to describe castles for research purposes. He summarized drawings and watercolors of Windau (Latvian: Ventspils) and other Livonian castles in a ten-volume manuscript „Sammlung verschiedener liefländischer Monumente, Prospecte, Müntzen, Wappen etc." became the most significant and extensive buildings' documentation from the late $18^{\text {th }}$ century to the first decades of the $19^{\text {th }}$ century. In the early $19^{\text {th }}$ century archaeologists, historians, regional researchers began to publish materials on Livonian castles in print editions. Certified forestry scientist Andreas von Löwis of Menar (1777-1839) in 1840 supplemented his article by a register of 143 Livonian castles. Russian authorities organized identification and documentation of ancient buildings. In the Courland Governorate Auditor of Mitau (also Mytowe, Mitowe, Mytove, Latvian: Jelgava) county C.G.Raetsch, Auditor of Pilten and Hasenpoth (Latvian: Aizpute) Heinrich Johann Cramer, Auditor of Goldingen Carl Willong prepared (1827-1830) a large collection of castles' views, plans, stands. It included in the album of Livonian castles, named after Governor-General of the Governorate of Livonia, Marquis Filippo Paulucci delle Roncole (1779-1849) (Livonija, 2008). Historian, Dr. Professor at the University of Dorpat Friedrich Karl Hermann Kruse (1790-1866) traveled (18381839) with archaeologists and surveyors and drew castles and plans for the issue "Necrolivonica oder Alterthümer Liv-, Esth- und Curlands" /Antiquities of Livonia, Estonia and Courland/ (1842). Johann von Radetzky the reflection on Courland's buildings published in "Malerische Wanderungen durch Kurland" (Radetzky, 1841). Sculptor, painter Wilhelm Siegfried Stavenhagen (1814-1881) steel engraved landscapes of historical buildings in Courland, Livonia, Estonia compiled in three volumes of "Album baltischer Ansichten" /The Album of the Baltic views/ (1857-1867). During Stafenhagen's lifetime unpublished drawings were included in "Neues Album baltischer Ansichten nach Zeichnungen von Wilhelm Siegfried Stavenhagen" /The new album of Baltic views based on drawings by Wilhelm Siegfried Stavenhagen/ (1913). Industrialist, historian Friedrich Ludwig Balthasar Amelung (1842-1909) issued "Bilder zur baltischen 
Kulturgeschichte" /Pictures of the Baltic cultural history/ (1879), "Baltische Kulturstudien" /The Baltic cultural studies/ (1885) and the Baltic cultural picture atlas (Amelung, 1886).

Architect Wilhelm Johann Carl Neumann (1849-1919) surveyed medieval castles, drew their stands, façades, plans and published it in the first essay on the Livs' lands, Estonia and Courland art history from the late $12^{\text {th }}$ century up to the late $18^{\text {th }}$ century (Neumann, 1887) and in a reflection on building history "Die Ordensburger im sogenannten Polnischen Livland. Mitteilungen aus der livländischen Geschichte" /Castles in so-called Polish Livonia. Messages from Livonian history/ (1889). In the article (Нейманъ, В.И. (1893). Военное зодчество въ прибалтийском крае въ средние века. In Tруды девятого археологического сьезда въ Вильне. Том I. Москва: 27-61) on military architecture of the Middle Ages in the Baltic region, Neumann for the first time in the Baltics defined construction periods of Livonian castles, described architectural details, plans, features of styles. Librarian from Riga, prominent researcher of castles by the 1930s Karl Woldemar von Löwis of Menar (18551930) included Livonian castles' plans and detail drawings in the encyclopedia (Löwis, 1922). Architect, historian of architecture Heinz Heinrich Gerhard Pirang (1876-1936) one chapter of three volumes work "Das baltische Herrenhaus"/ The Baltic manor house/ (1926-1930) devoted to castles, where after rebuilding in the $16^{\text {th }}-19^{\text {th }}$ centuries the noble families continued to live. Latvian historian Cand. hist. Anna Grēvinia in edition on medieval castles (Grēvina, 1936) and Cand. hist. et phil. Žanis Karlsons (1899-1976) in issue on the Order's era (Karlsons, 1936) compiled pictures and news of Livonian castles. In Volume 16 of the Latvian Conversion Dictionary (1937-1938), Leonid Arbusow (18481912) his article supplemented by a list of 105 names of castles on the territory of Latvia (Ose, 2001, 25). A collective monograph "Baltische Lande"/The Baltic countries/ (1939) was devoted to German-founded towns and castles on Prussian and Livonian lands. Editor-in-chief (1928-1939) of "Baltische Monatshefte", Dr. Professor (1935-1939) at Herder's Institute in Riga Reinhard Wittram (1902-1973) after his departure published a book "Baltische Geschichte. Die Ostseelande Livland, Estland, Kurland 1180-1918” /The history of the Baltic Sea Region: Livonia, Estonia, Courland 1180-1918/ (1939). Prominent researcher of fortresses in the Baltics, Estonian art historian, Dr. phil. Professor at the University of Tartu Armin Tuulse (1907-1977) published studies on Livonian strongholds' history and architecture. He considered that the second construction period (1237-1400) of castles was before the use of firearms began (Tuulse, 1942). Austrian theologian Marian Tumler (1887-1987) wrote the Teutonic Order's short history (Tumler, 1954). German historian Dr. Professor Hartmut Boockmann (1934-1998) completed the Teutonic Order's history in twelve chapters (Boockmann, 1981). German historian, Dr. Professor Udo Arnold 
(b. 1940), Polish historians Dr. Professor Zenon Hubert Nowak (1934-1999) and Dr. hab. hist. Professor Marian Biskup (1922-2012) established regular international conferences to discuss the Teutonic Order's history. The first meeting (1981) took place in Toruń. Beyond Ordines militares conferences held every two years. The International Commission for the Teutonic Order's history research (German: Internationale Historische Kommission zur Erforschung des Deutschen Ordens; 1985) was established to attract and coordinate historians from other countries to expand the Order's research as a phenomenon throughout European history. German scientists studied the Teutonic Order's activities in the Baltic and issued a collaborative work - the dictionary of historical place names "Baltisches historisches Ortslexicon, II: Lettland” (1990). Historian Lutz Fenske and contributor of the Historical Archives of the City of Cologne, Dr. Professor at the Georg-August University of Göttingen and the Ruhr-University Bochum Klaus Militzer (b. 1940) wrote about the knights in the Livonian branch (1237-1562) of the Teutonic Order (Fenske \& Militzer, 1993) and research (Milicers, 1994). The monograph „Die Geschihte des Deuchen Ordens”/The history of the Teutonic Order/ was issued in German (2005) and in Latvian (Milicers, 2009). A collaborative work "Deutsche Geschichte in Osten Europas: Baltische Länder" /German history in Eastern Europe: Baltic countries/ (Pistohlkors, 1994) was issued in Gert Olof von Pistohlkors' (b. 1935) edition. Friedrich Wilhelm Benninghoven (1925-2014) published the history of the Teutonic Order, Gdańsk, Oliva monastery and the conquest of East Prussia in 1945 (Benninghoven, 1996). Specialist in military history, academician Dr. Stephen Turnbull (b. 1948) summarized news on stone castles of Prussia (Turnbull, 2003), Latvia, Estonia (Turnbull, 2011). Archaeologist, academician, Dr. hab. hist. Professor Andris Caune (b. 1937) informed on archaeological research in towns of the $13^{\text {th }}-16^{\text {th }}$ centuries (Caune, 2014) and together with the full member of Latvian Academy of Sciences Dr. hist. Ieva Ose compiled a lexicon of German Castles (end of the $12^{\text {th }}-17^{\text {th }}$ century) in Latvia (Caune \& Ose, 2004) and studies on medieval churches and chapels in castles (Ose, 2011). In "Archaeology and Architecture of the Military Orders. New Studies” (Torbus, 2016) has been published new researchs.

Previously published studies on castles founded by the Teutonic Order in Courland and Semigallia: Ulrich Heinrich Gustav Freiherr von Schlippenbach (1774-1826) descriptions of castle ruins published in travel notes on picturesque walks through Courland (Schlippenbach, 1809). Researcher of Ancient-times Hermann Friedrich Waeber (1761-1833) depicted in watercolors (the late $18^{\text {th }}$ century-the early $19^{\text {th }}$ century) Goldingen (Latvian: Kuldiga) and Kandau (or Candowe, Latvian: Kandava) castles (Meinarte, 2002, 389-407). Painter Julius Friedrich Döring (1818-1898) during his travel through Courland and Semigallia drew castle ruins in notebooks. Cand. hist. Nikolajs Ķaune (1903-1939) studied 
Mitau Castellum (Kaune, 1936), archaeologist, academician, Guntis Zemītis published results on archaeological research of this castle (Zemìtis, 2005), but painter, Dr. art. Imants Lancmanis pronounced his conclusions on new discoveries of the Old Castle of Mitau (Lancmanis, 2010). Carl Meißner published a book about Courland, the beautiful German country (Meißner, 1917). Researcher of Goldingen history, teacher Ernst Hennig on a castle, the town and churches published "Kurländische Sammlungen. Herausgegeben von Ernst Hennig. Ersten Bandes I Theil" (1908) as the first volume (I part) of Goldingen town history "Geschichte der Stadt Goldingen in Kurland". Assistant (since 1895) to Head of Marienburg (Polish: Malbork) Complex reconstruction, protector of antiquities, Dr. h. c. Professor Bernhard Schmid (1872-1947) surveyed castles in Courland, drew stands, façades and sections, defined construction periods, prepared descriptions and published until World War II the only work on castles and churches in Courland (Ose, 2001, 19 and 54). Results of research and measurment drawings (1916-1917) of Goldingen town and castle he published in issue on the Teutonic Knights' castles in Courland (Schmid, 1921). Director of Kuldiga German Primary School, the founder of Kuldiga Regional Museum Walfried Fromhold-Treu (1886-1964), who from 1930 to 1939 lived in Kuldiga, studied the castle-site, materials in archives and documents belonging to individuals, created the reconstruction drawing of Goldingen Castellum and published it in the illustrated annex of newspaper „Briv $\bar{a}$ Zeme” Nr. 68. He also planned to publish an illustrated book on Goldingen Castellum, but the original manuscript of the reconstruction explanation died in 1945. Fromhold-Treu, living in Germany, re-wrote his work in 1947. After researcher's death, sons prepared a reflection on the Goldingen Commandery "Die Komturei Goldingen. Versch einer Rekonstruktion" and published it in the Courland Knighthood Magazine "Kurland" (in Germany). Unpublished reconstruction drawings of Goldingen Castellum and manuscript (in German) (Fromholds, 2005) were donated (1992) to Kuldiga Regional Museum, that issued a book (Dzenis \& Dzene, 2015) written by historian Mg. hist. Agris Dzenis and Irma Dzene. Dzenis also collected historical news on Kandau Castellum (Dzenis, 2011). "Proceedings of the Ventspils Museum" (since 2001) includes an article on Windau Castellum in the $13^{\text {th }}-16^{\text {th }}$ centuries (Lūsēns, 2002), written by archaeologist Mārtiņš Lūsēns, and Dr. arch. Ilmārs Dirveiks studies on this castle in the early construction phase (Dirveiks, 2004). Dr. hab. art. Professor Ojārs Spārītis studied the Baltic Germans (German: Deutschbalten) cultural values in Courland (Spārītis, 1995).

Previously published studies on castles founded by the Teutonic Order in the State of the Teutonic Order: German historian, Professor at the University of Königsberg (German: Albertus-Universität Königsberg) Johannes Voigt (1786-1863) wrote Prussian (Old Prussian, Lithuanian: Prūsai; German: Pruzzen or Prußen; Latin: Pruteni; Latvian: prūši; Polish: Prusowie) history from ancient 
times to the end of the Teutonic Knights' rule (Voigt, 1827-1839) and handbook of the history of Prussia up to the Reformation (Voigt, 1842-1843), NamesCodex of the Teutonic Order's officials, Grand Masters (Latin: magister generalis, German: Hohmeister) or Knight Commanders, Masters, a large area in Prussia (Voigt, 1843) and the Teutonic Knights' history (Voigt, 1857-1859). Head of Marienburg (Polish: Malbork) Complex reconstruction, architect Conrad Steinbrecht (1849-1923) from Prussia became the author of books richly illustrated by façades, plans of castles and architecture in Prussia (Steinbrecht, 1888 and 1910). Bernhard Schmid published his study on Teutonic Knights' castles in Prussia (Schmid, 1938). German scientist of art, Dr. phil. Professor at the University of Rostock Karl Heinz Clasen (1893-1979) in monographs on the Teutonic Order's Lochstedt Castle (Clasen, 1927) and medieval art characterized the spatial structure of stone castles and its layouts in the Teutonic Order State (Clasen Kunst, 1927). Historian of architecture, architect Bohdan Guerquin (1904-1979) included materials on architecture, layouts, the stands and analysis of the fortresses' impact on towns' building in his book dedicated to castles in Poland and defined construction periods for castles built on Prussian lands conquered by Teutonic Knights. The first construction period (1230-1320) began in 1230 with the first stone fortress built for military purposes and continued until 1320, when Grand Master's residence was transferred to Marienburg (Guerquin, 1984). Carl Wünsch collected information on architecture of castles and churches in East Prussia (Wünsch, 1960), but urban planner, historian of architecture, Dr. hab. inz. arch. Professor Andrzei Tomaszewski (1934-2010) and Professor Antoni Kąsinowski compiled information of castles in Poland, but Polish professor of archeology, a specialist in the field of construction and defense and residential architecture in Poland during the Middle Ages Leszek Kajzer (1944-2016), historian, Dr. hab. Stanisław Kołodziejski (1951-2019) and Jan Salm are authors of the lexicon of castles in Poland (Kajzer, Kołodziejski, \& Salm, 2001, 2010). A detailed overview of four-unit castles of regular layout can be found in the book about convent castles in the Teutonic Order's land of Prussia (Torbus, 1998) written by Dr. hab., Professor Tomasz Torbus. Art historian, Dr. hab. Professor at Institute of Art History of the University of Gdańsk Christofer Herrmann (b. 1962) specialized in studies of medieval architectural monuments, researched art landscape and medieval architecture in Prussia (Herrmann, 2007).

Research problem: construction of stone castles contributed to the growth of populated areas in lands populated by the Baltic tribes, and Catholic congregations were established. The influence of cult buildings' location on layouts of castles built by the Teutonic Order has not well researched. Research novelty: castles of the Teutonic Order are studied in the context of Italian architecture. Research goal: analysis of the impact of cult buildings on 
construction structure of stone castles and planning of fortified power centres in the Teutonic Order State in order to determine common and different characteristics. Main methods: inspection of buildings and urban planning in nature, studies of archive documents, projects and cartographic materials.

\section{The specific of formation primary fortified urban structures in secular power centres of the Teutonic Order State}

In Culmland, a ringwall (German: Ringmauern) for horseshoe-type strong fortified Thorn (Polish: Toruń) Castle was built close to the Prussian settlement at the Weichsel (Polish: Wista) Waterway. On the stronghold's western side next to the river, regular planning Old Town of Thorn developed instead of the settlement, obtained Magdeburg rights in 1233. During construction of Marienburg Castle, Thorn became the capital of the Teutonic Order State. An urban construction decision in 1236 was made on the citadel's formation on the relief elevation (Kranz-Domasłowska, 2013). The massive single-unit stone castle began to erect around 1255. Buildings added to the wall's inner edge. The fortress included a chapel mentioned in 1263 (Torbus, 2016, 226).
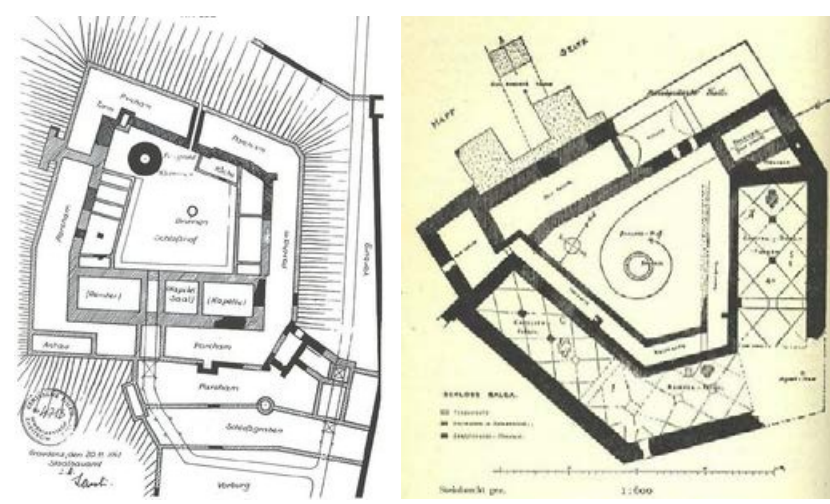

Figure 8 Graudenz Castle plan with the chapel at the building's southeastern coner (online 08.07.2017, https://s-media-cacheak0.pinimg.com/236x/34/62/ba/3462ba18a7eb281a3ebaacdc727d398d.jpg)

Figure 9 Architect Conrad Emanuel Steinbrecht (1849-1923). Hexagonal Balga Castle with the chapel in the eastern side (Steinbrecht, 1888, 101)

On the right bank of the Weichsel River, instead of the Prussian settlement, construction of Graudenz (Prussian: Graude, also Graudenes - giant forest) stone stronghold for border defence began around 1250-1260. Buildings added next to the inside edge of brick defensive walls. The entrance gate, reception rooms and the chapel were made in the big southren block (Fig. 8). After 1300, the western block erected on the river's coast, to which a low-rise building placed on the terrace faced to the town. 
In Balga (Russian: Бальга, Polish: Batga) on the Weichsel (Latin: Vistula) Lagoon's (German: Frisches Haff) coast, construction of the irregular hexagonal horseshoe-type stronghold (1270-1280) of stone began for the Teutonic Order State's centre (Benninghofens, 2011, 17). Houses placed along yard's perimeter, the gate was on the northern side where a harbour located. The Chapter Hall and a dinning-room situated on the three-part block's eastern side. East-westwards orientated two-nave chapel (Fig. 9) had four bays. The church located in the settlement on the south side. An impressive front-castle was made around 1290.

\section{Castellum-type castles built by the Teutonic Order in Courland}

The city of Lübeck, that located on the coast of the Baltic Sea, and the city of Hamburg, that located on the coast of the North Sea, in 1241 signed a trade agreement that can be considered as the origin of the German Hansa (Latin: Hansa Teutonica, German: Deutsche Hanse) by the centre established in Visby. Merchants from Lübeck needed new support places near big waterways and river estuaries on the Baltic southern coast and proposed to establish in Sembia a town at the estuary of the Pregel River. However, the idea was unimplemented.

In Courland, in order to increase the Teutonic Order's impact, on 19 April 1241, it was allowed to build a fortress or a town along the Winda (also Wynda, Latvian: Venta) River "on a spot where it seems the most convenient”. The Rus' force under the command of Prince of Novgorod (1236-1240 and 1241-1256), Grand Prince of Kiev (1236-1252) Alexander Nevsky met the enemy on the ice of Peipus Lake and defeated the German knights and the Estonian infantry during the Battle of the Ice on 5 April 1242 and prevented the German feudal lords from going east. The Teutonic Order continued to concentrate its efforts on conquering of lands inhabited by the Cours and the Semigallians in order to establish new centres of aggression. On the ford in a strategically convenient place southwards the Cours' hillfort, Master of Livonia (1242-1245) Dietrich of Grüningen decided to build a castle for surveillance of the Winda Waterway and road from the Teutonic Order's State to Riga. The Prussians in 1243 started first revolt, and Vice Master (1240-1241, 1248-1253) Andreas of Felben and bishops of Riga, Dorpat, Ösel-Wiek signed on 1 October 1243 an agreement to found the Livonian Confederation (Latin: Terra Mariana; 1243-1561).

Legate (1224-1251) of Pope, bishop Wilhelm of Modena, purposeful implementer of Pope's politics, on 7 February 1245 admitted Courland on part of Prussia (Curonia seu Curlandia, cum sit pars Pruscie), and on 9 February 1245 Pope confirmed this decision (Šterns, 2002, 367). A new version for the Teutonic Order's regulation (German: Ordensregel) worked out from 1244 to 1251. The Teutonic Order's regulation, dated from 1264, determined the division of orderbrothers into secular brothers (German: leigebruder) or brothers-knights 
(German: Ritterbrüder) and spiritual brothers-priests (German: Priesterbrüder). Twelve monks had to be under the commandant or commander (Latin: commendator, praeceptores, German: Komtur, Kommentur) or Vogt's (Latin: advocatus, German: vogd, voit, vogt) subjugation: two of them were brotherspriests, but the others - brothers-knights. All brothers of the Order had to give the monks' promises of poverty, chastity and obedience and they had to promise to fight against pagans. The second paragraph of the regulation stated that in the joint ownership there could be fields, vineyards, mills, fortresses, villages, parishes, chapels, people - men and women, and slaves - men and women. In the Chapter of Order, Grand Master or the "Jesus Christ's assistant" for the Brothers of the Order was elected for life. Head or Grand Marshal (German: Großmarschall) was in charge of war affairs and managed troops instead of Master. The Order's all brothers together - the brothers-knights of the castle-region, priests and servants were called the convent (Šterns, 2002, 418-420), who had to live in monasteries. The knights used as samples castles (German: Kreuzfahrerburgen) and monasteries in Italy and Syria. In Livonia, the second construction period (1237-1400) related to the Teutonic Order's stone castles began. Historian of architecture, Cand. art. Yuri Vasilyev (Latvian: Jurijs Vasiljevs; 1928-1993) believed, that the medieval period in architecture of Latvia (the late $12^{\text {th }}$ centurythe first third of the $16^{\text {th }}$ century) had several stages. The second stage (the second third of the $13^{\text {th }}$ century-the late $13^{\text {th }}$ century) covers time of active armed struggle to establish a rule of German feudal lords in the Baltic (Васильев, 1986).

The Peace Treaty signed on 7 February 1249 in Christburg (Milicers, 2009, 101) determined civil and personal freedom to the Christians. The Prussians finished revolts, even in some places though fights continued until 1253. Grand Master did not fulfil the obligations: he made a decision on the territorial division of the Prussian lands, started to establish administrative structures and erected wooden fortifications of irregular layout instead former Prussian buildings. In the second half of the $13^{\text {th }}$ century, construction of castles expanded. Monks creatively looked for solutions of fortress construction and planning, applying slim supports and vaults for interiors. Defensive walls (German: Wehrmauern) with an allure (German: Wehrgänge), towers (German: Türme) and gates (German: Tore) were taken over from the protective system of stone strongholds in Rhineland (German: Rheinlande) and Frankish lands.

Master of Livonia and Prussia (1249-1254) Dietrich of Grüningen, believed to be conqueror of Courland, built (1252) Memell (Lithuanian: Klaipeda) wooden fortress instead of the Cours' ruined town at the Dange mouth, in order to monitor traffic on waterway and landroad from the State of the Teutonic Order to Riga (Benninghofens, 2011, 12-13). Regions inhabitad by the Cours were added to the Livonian State, and borders were clarified in April 1253. Authorised by Grand Master of the Teutonic Order in Livonia (1251-1254) Eberhard of Sayn (Latin: 
Everhardus Seyn) turned to conquest the lands that separated the State of the Teutonic Order from Livonia. In 1253 during two months' time, Memelburg Castle of stone (castrum Memele, castrum inter Mimelam et Dangam, castrum Mimelburch, borch to Mimelborgh) was built on an island on the Dange (also Dane, Danija, Akmena) River.

The Sembian wooden fortifications Twangste (Prussian: tvinksta - a pond made by a sluice) on a high hill were destroyed, and Königsberg (from 1946 Russian: Калининград) fortress on a strategically and geographically convenient place on the left bank of the Pregel River at the estuary in the Baltic Sea were built for the waterway's surveillance. A hall-type St. Nicolay's Church (1264, destroyed in 1828) erected on the fortress' southern side had naves of equal height. The Cours, the Semigalians, the Latgalians and the Prussians in 1260 began their riots, and construction of defensive walls and Königsberg (Prussian: Kunnegsgarbs, Lithuanian: Karaliaučius, Polish: Krolewiec; 1255-1325) stronghold of stone begun, and wooden fortress was completed in 1261. The establishment of new fortified support places in Prussia temporarily interrupted.
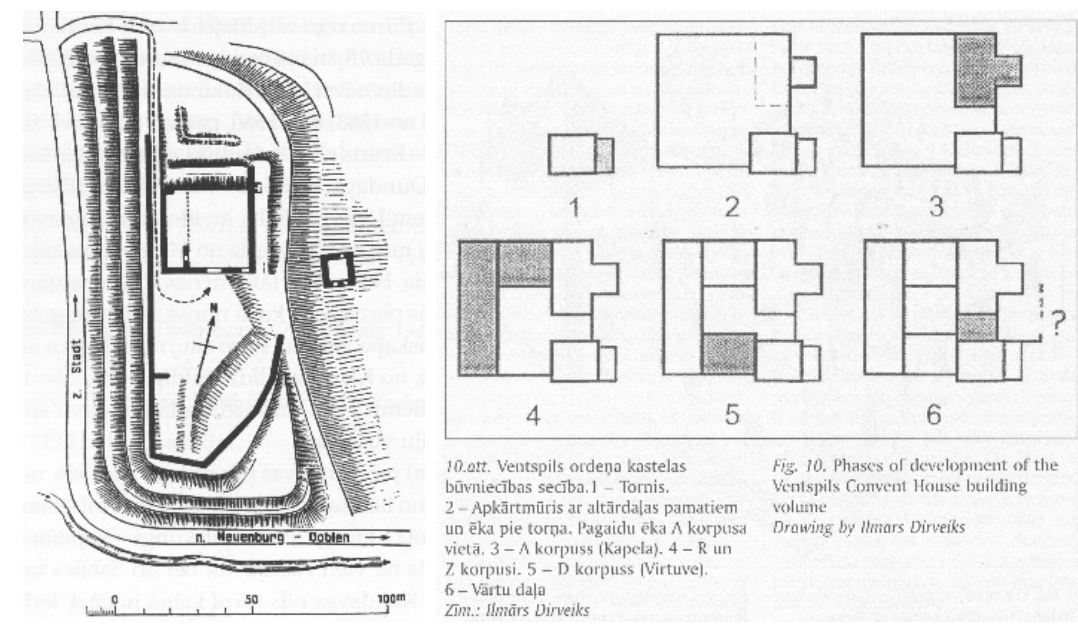

Figure 10 Prominent researcher of castles Karl Woldemar von Löwis of Menar (1855-1930). Plan of Kandau Castellum (Caune \& Ose, 2004, 240)

Figure 11 Architect Dr. arch. Ilmārs Dirveiks. Development phases of four-unit Windau Castellum with the chapel (Dirveiks, 2004, 152)

In Vanema, on the Abava Valley's corner southwards from the Cours' hillfor, where two lowlands meet and the Abava River turns its original westeast flow towards the north, a thick defensive wall on an elongated projection by three steep sides and square Kandau Castellum with a chapel were built until 1312 (Caune \& Ose, 2004, 22). The castellum together with the external front-castle on the north and the urban settlement (oppidum) in the south made a three-part fortified building complex (Fig. 10). The citizen Catholic congregation's church located at hillfort's foot on crossroads near a marketplace of irregular layout 
(Caune \& Ose, 2004, 239-242). German merchants and craftsmen set up their homes on road near the castle (Ozola, 2013).
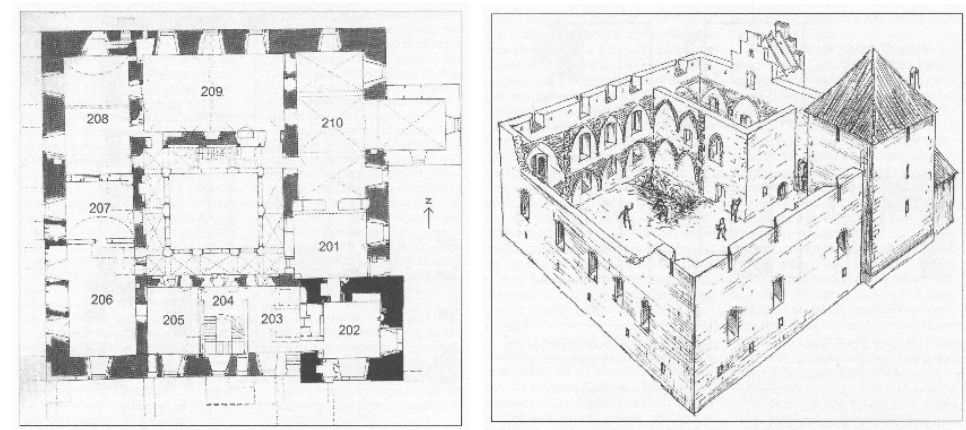

Figure 12 Ilmārs Dirveiks. The first floor plan of Windau Castle. Chronology of the $14^{\text {th }}$ and $15^{\text {th }}$ century building blocks (Dirveiks, 2004, 137)

Figure 13 Ilmārs Dirveiks. Reconstruction drawing of Windau Castle's outer wall with the chapel. (Dirveiks, 2004, 151)

Bishop Heinrich and Master (1263-1266) Konrad of Mandern in 1263 signed the agreement about ownership of ports belonged to the Cours and the Semigallians. On the Baltic seacoast, for economically important surveillance of the Winda River estuary, the residential tower was built (around 1270) on the hill at land road, which took to the Winda Port and a marketplace. The construction of four-unit Windau Castellum (around 1270-1280) began. Building work sequence (Fig. 11) related to functions: after construction of the freestanding fourstorey residential tower of stone and defensive wall, the formation of the chapel and the Chapter Hall followed (Fig. 12, 13) (Dirveiks, 2004, 142). Jurij Vasiljev believed, that the third stage from the 1290 s to the mid- $15^{\text {th }}$ century began with the strengthening of institutions of feudal society after the Crusaders suppressed the last centres of resistance of local residents. Trade and craft cities that arose in the $13^{\text {th }}-15^{\text {th }}$ centuries, including Wenden, after Riga joined the German Hansa. German feudals divided occupied lands, and construction intensified. Relatively simple castellum-type castles consisted of a fortress wall, surrounding a rectangular courtyard, laid out of boulders in Livonia. Residential and utility buildings attached to it, like the Order's castle in Hasenpoth (last quarter of the $13^{\text {th }}$ century) (Vasiljev, 1986, XLII-XLIII).

\section{The creation of early four-unit building complexes with the chapel}

In the protection zone of the large Weichsel Waterway, the Teutonic Order began to set up camps for maintenance of military forces, food and weapon storage, traffic and trade provision in Prussia and people's refuge. Until 1260, castles erected at a certain distance to close territorial crossings 
(Milicers, 2009, 103). Elbing Castle (1246) on the side of the Weichsel Lagoon, Königsberg and Marienburg fortresses were early fortifications of regular layout.

On the north-west side of Königsberg stronghold mentioned for the first time on 29 June 1256, merchants from Lübeck created the settlement of regular layout. Construction of the wooden fortress for the Pregel Waterways' surveillance completed in 1261, but the fire in 1262 destroyed houses. A significant centre with the trade port in the Baltic Sea region around 1263 was made. Nevertheless, the town foundation was unsuccessful. Vogt of Samland (1278-1292) Dietrich von Liedelau built the north part of stone fortress and in its northeast corner - a Haber Tower (German: Haberturm, destroyed during 1941-1945 in the war) of octagonal layout. In January 1286, the Old Town was founded. High, thick defensive walls and six towers were built. The bell placed in the freestanding tentlike roof covered tower (Fig. 14) next to the external wall. A reception room in 1312 was made and on its south side - a single-nave Castle Chapel, that had four bays. Later the Castle Church was created (Fig. 15).
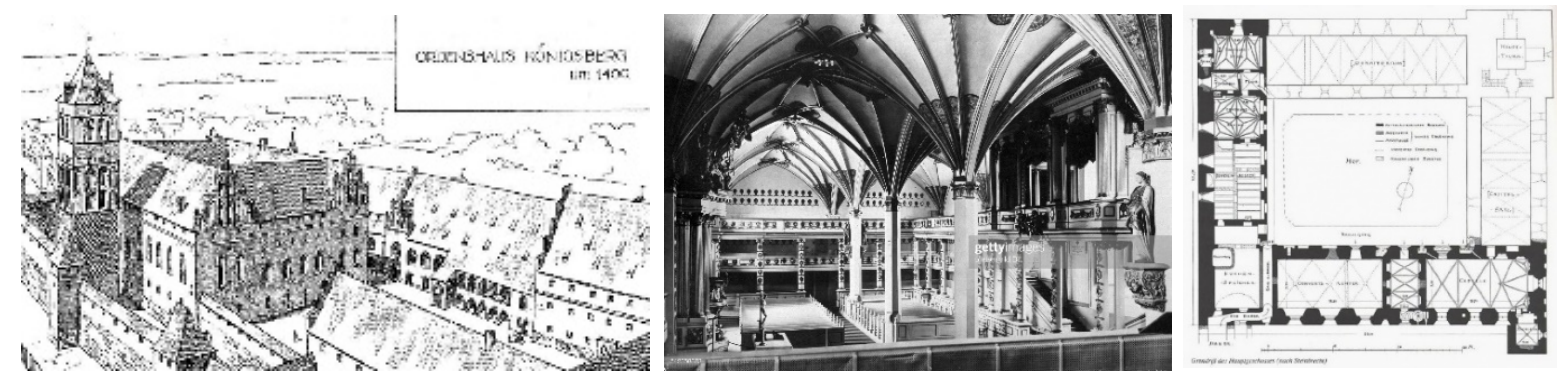

Figure 14 Historian, Dr. hab., Professor Torbus Tomasz. View on the tower and the chapel (around 1400) located in Königsberg Castle's southeastern corner. 1998

(Vartberge, 2005, 227)

Figure 15 Interior of Königsberg Castle Church (Wünsch, 1960, 39)

Figure 16 Conrad Steinbrecht. Reconstruction of Lochstedt Castle plan with a chapel at building's southeastern corner. 1882, 1902 (Steinbrecht, 1910, 14)

On the coast of the bay, on a land strip of the Weichsel Lagoon - an early a regular planning four-unit Lochstedt (Russian: Павлово) Castle (1270-1275, destroyed during World War II) was erected (Fig. 16). The second-floor plan of the southern block was symmetrical: in the west, there was a dinning-room, in the middle - a small room joined with the cloisters, also covered walks, open galleries or arcades running along walls of buildings. Stairs, made in the external wall, took to the first floor. In the east, there was the chapel, which main entrance took from the cloisters surrounded the tyard. The Chapter Hall's end-wall door clung to the chancel of vaults covered small chapel in the northern side, which joined both rooms. The sacristy located on the chapel's south side. 
In 1237, the Teutonic Knights, on behalf of the Roman Catholic Church, conquered the region and the native pagan Old Prussian inhabitants dispersed in the process. The Teutonic Order built a castle at the lake and founded Elbing with a population mostly from Lübeck. In 1246, the town granted a constitution under Lübeck Law, providing for self-government as a free city. In the State of the Teutonic Order, Grand Marshal's residence situated in Königsberg, the main hospital (German: Großspittler) - in Elbing (Elwinge, Polish: Elblag; 1237), the main Trapier (German: Großtrappier) - in the trans-regional centre Christburg (1247, destroyed in the $15^{\text {th }}$ cent.). Castles for Komturs and Vogts became political and economic centres. In 1271, the Teutonic Order made a decision to build the capital of the Teutonic Order State (1308-1454) on the Nogata right coast near Danzig-Truso road (Guerquin, 1984, 209) to place Grand Master's (German: Großkomtur) residence. Defensive walls for the fortress were built, and the ditch was dug (1274-1275). The square Meeting or Upper Castle (German: Vorschloss; 1276) as a monastery of brick for the convent of brother-knights was erected. It was also the administrative and cult centre. The chapel highlighted by corner towers was orientated along the east-west axis and clung to the square. On 27 April 1276, Grand Master (1273-1276) Konrad of Thierberg (Latin: Cunradus de Tyrberch, now Thierenberg) after St. Mary, patroness of the Teutonic Order, named the fortress as Marienburg. Regular four-unit Tapiau (Russian: Гвардейск) Castle, built in 1280 on the right coast of the Pregel, served to protect the border and defend approaches to Königsberg.
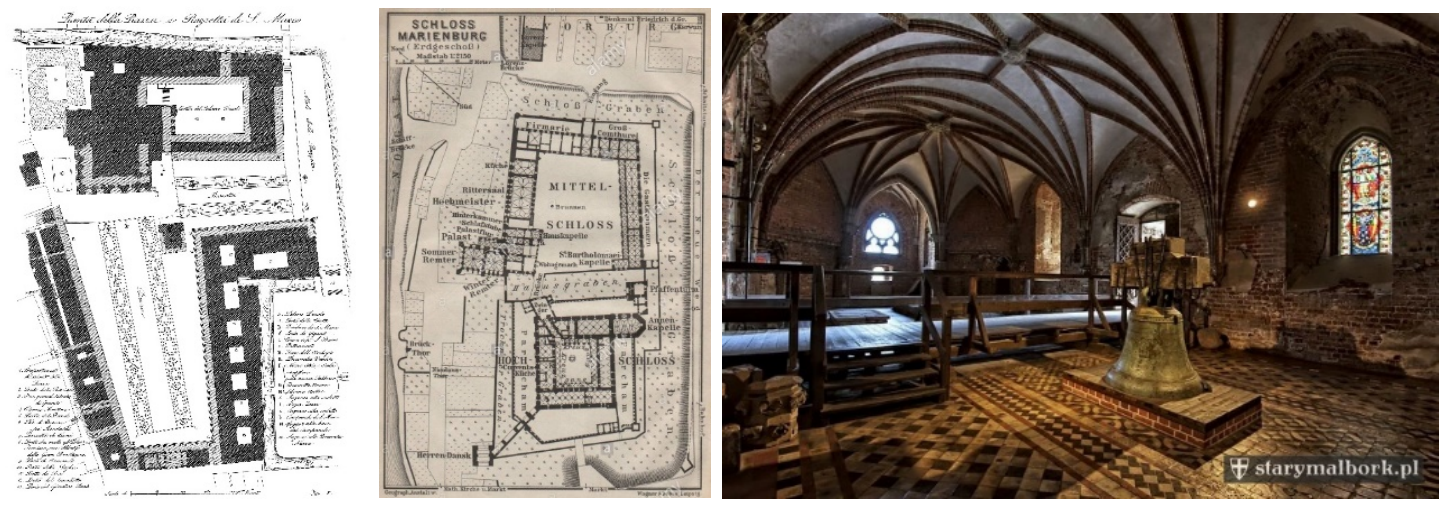

Figure 17 Italian printmaker Moretti Dionisio (1790-1834). Plan of San Marco Square in Venice, in XVI. tables. 1831 (Moretti, 1987)

Figure 18 Geographer Anstalts. Plan of Marienburg complex with the Upper Castle and a tower on the eastern side of St. Anna's Chapel (Anstalt, 1904)

Figure 19 St. Anna's Chapel in Marienburg Castle (online 04.03.2018, http://4.bp.blogspot.com/-cDDLuq57-

LQ/UDKdvHfFc3I/AAAAAAAAGj8/3nFLiiSSRJ0/s1600/IS_DSC_5080_2_6+kopia.jpg) 
In Venice, St. Mark's Square in the late $13^{\text {th }}$ century transformed, making it open towards the city. St. Mark’s Square, surrounding buildings and the fortified building complex of the Dodge's Castle with St. Mark's Cathedral included in perimeter construction, became part of the city centre composition (Fig. 17). The Christians in 1292 lost the Holy Land, and the Teutonic Order's Grand Master from Akko escaped to Venice. On flat relief, he built (1291-1309) for the convent a rectangular castle with a yard protected by a ringwall. The garrison, household, warehouse buildings arranged along a perimeter.

In Marienburg, a sacral building was included in the block of the square Upper Castle (Fig. 18), to which the courtyard clung. A solution was found in compliance with the idea incorporated in the Cistercian monastery's functional scheme. The Juranda Canal (Polish: Młynówka) connected with the Nogata River, was dug (at the turn of the $13^{\text {th }}-14^{\text {th }}$ cent.) for the improvement of the defence system, and it surrounded the complex. In 1309, Grand Master (1303-1311) Siegfried (also Zygfryd) von Feuchtwangen moved his residence to the Teutonic Order State's capital Marienburg. Venice was used as a sample. The perimeter building of the Middle Castle (German: Mittel-Schloss; after 1310) surrounded the Upper Castle, and a wide yard was created (Fig. 18). The administrative centres of the Middle Castle and the Lower Castle (German: Hochschloss) or front-castle - the economic base of the fortified complex, were built on the plain of the river coast. Under the cover of the front-castle, the Middle Castle plan that reminded of a spacious trapezoidal yard, surrounded by the perimeter building, joined to the monastery's regular courtyard. A three-division complex was made in several stages. St. Mary's Church (Sankt Marien-Kirche, 1344) was reconstructed and St. Anna's Chapel (German: Sankt Annenkapelle, 1331-1344) (Fig. 19) got under its auspices (Ozola Tower, 2018).

\section{Creation of the four-unit castle of square layout called the convent-house}

Around 1290, mutually linking four blocks of an even height created a castle of square layout (Milicers, 2009, 108) named in the Latin phrase domus conventuales. The following were built Gollub (Fig. 20) and Rehden (Fig. 21) castles reminded not only of a monastery with cloisters, but also performed functions similar to monastery's cloisters. On the top floor - the monks' common bedroom (Latin: dormitorium), the Chapter's Meeting Hall, dining-room, administration rooms, a room for the Komtur or Master. 
Ozola, 2020. The Forming of Castellum-Type Castles and Four-Unit Building Complexes with Chapels in Secular Power Centres of Courland and the State of the Teutonic Order
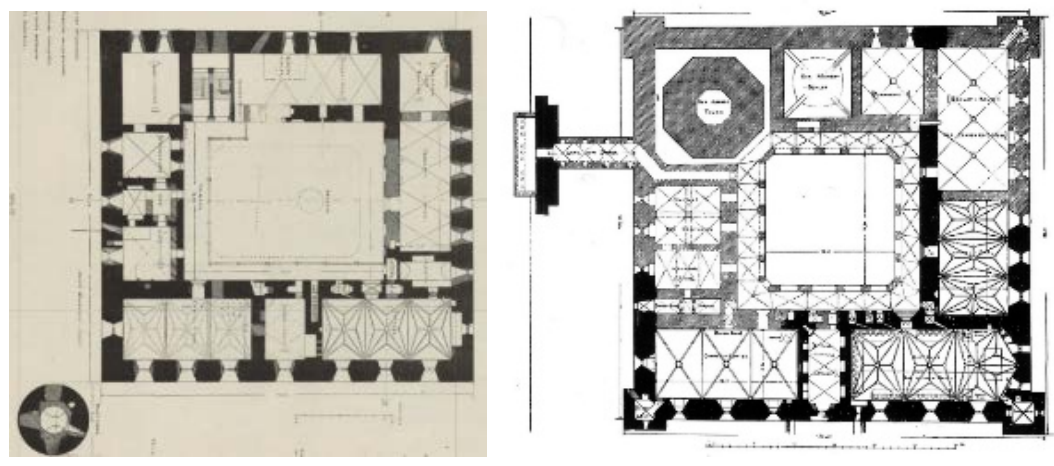

Figure 20 Conrad Steinbrecht. Plan of four-unit Gollub Castle with a chapel at building's southeastern corner around 1300 (Steinbrecht, 1888, 33)

Figure 21 Plan of the four-unit Rehden Castle with a chapel at building's southeastern corner (online 04.03.2018, https://medievalheritage.eu/wp-content/uploads/2017/02/RadzynChelminski-plan-02.jpg)

Tuulse in his book it called the convent-house (German: Konventhaus) (Tuulse 1942). Elbing Castle for Komtur in the $14^{\text {th }}$ century was rebuilt into a regular structure, but a strong fortified bishop's residence, Canonical Chapter's residence and basilica - St. Nikolay's Cathedral (Polish: kościót katedralny św. Mikołaja; $1240-1260$ ) used for religious and social activities up to the $14^{\text {th }}$ century were built separately from the urban building.

In Courland, on the Winda River's left bank, where the Cours' settlement existed fifty years before the Germans' wooden fortress was built for the Goldingen Commandry's Centre, four-unit stone regular Goldingen Castellum in the late $13^{\text {th }}$ century replaced former fortifications. On the second floor of the northern block there was the Chapter's Hall joined with the chapel in the northwest corner. The chancel only might have formed the chapel, as the congregation could sit in the Chapter Hall (Fromholds, 2005, 238, 258).

On the Long Island, made by the Lielupe River and its bypass Driksa, Mitau wooden fortress (1265-1266) in 1272 became the military base for the conquest of Semigallia, Lithuania and Courland. Master of Livonia (1328-1340) Eberhard of Monheim (Everhardus a Monheim) built Mitau Castellum of bricks, boulders and dolomite, beside which craftsmen and merchants made an urban settlement (Hakelwerk Mitau) by compact building of dwellings, household houses and warehouses. The Lithuanians under Grand Duke (1345-1377) Algirdas' leadership in 1345 burnt the front-castle (Zemītis, 2005, 185).

\section{Conclusions}

In Livonia, during the second stone fortresses construction period, the chapel was included in the volume of the castle, so that the internal yard would be placed 
in the south. In a regular four-unit castle the chapel was included in a separate block, and construction of such fortresses was also on a flat relief started. In Prussia, during the first stone fortresses construction period, the chapel in regular planning castle was included in the south. The tower became the architectonic dominant of the castle. Near the fortress, the church was built. The planning of Commandry and Vogtei centres obtained first outlines.

\section{References}

Anstalt, W. (1904). Schloss Marienburg. Erdgeschloß. Leipzig: Wagner \& Debes.

Amelung, F. (1886). Baltischer kulturhistorischer Bilderatlas. Dorpat: Schnakenburg Werlag.

Benninghofens, F. (2011). Pilis kā galvenie atbalsta punkti vēlo viduslaiku aizsardzības sistēmā

Vācu ordeña valstī Prūsijā un Livonijā. In Latvijas viduslaiku pilis, VII. Pētījumi un avoti par Livonijas ordeņpilīm (9-51). Rīga: Latvijas vēstures institūts.

Benninghoven, F.W. (1996). Zur Geschichte des Deutschen Ordens, der Stadt Danzig, des Klosters Oliva und zur Erberung Ostpreussens 1945 Unzensierte Nachtr. zur Ostforschung. Berlin: Selbstverlag.

Boockmann, H. (1981). Der Deutsche Orden. Zwölf Kapitel aus seiner Geschichte. München: Beck.

Caune, A. (2014). Arheologiskā pētniecība Latvijas 13. - 16. gs. mazpilsētās. Latvijas Zinātņu Akadèmijas Vēstis, Part A, Volume 68, Nr. 5-6, 4-22.

Caune, A., \& Ose, I. (2004). Latvijas viduslaiku pilis, IV. Latvijas 12. gadsimta beigu-17. gadsimta vācu pilu leksikons. Rīga: Latvijas vēstures institūta apgāds.

Clasen, K.H. (1927). Die Deutschordensburg Lochstedt. Königsberg: Gräfe und Unzer Verlag.

Clasen, K.H. (1927). Die mittelalterliche Kunst im Gebietedes Deutschordensstaates Preußen. Die Burgbauten. Königsberg: Weidlich Reprints. de Dusburg, P. Chronicon Terrae Prussiae.

Dirveiks, I. (2004). Ventspils Livonijas ordeṇa pils būvvēstures agrīnais periods. 13. gs. otrā puse-14. gadsimts. Ventspils Muzeja Raksti IV, 133-172.

Dzenis, A. (2011). Vēstures ziņas par Kandavas pili un Pulvertorni. In Latvijas viduslaiku pilis, VII. Pētījumi un avoti par Livonijas ordenpilìm (291-322). Rīga: Latvijas vēstures institūta apgāds.

Dzenis, A., \& Dzene, I. (2015). Kuld̄̄gas pils - senās Kurzemes sirds. Kuldīga: Kuldīgas novada muzejs.

Fenske, L., \& Militzer, K. (1993). Ritterbrueder in livländischen Zweig des Deutschen Ordens. Koeln-Weimar-Wien: Böhlau.

Fromholds-Treijs, V. (2005). Kuldīgas komturejas pils rekonstrukcijas mēginājums. In Latvijas viduslaiku pilis, V. Pêtījumi par Kurzemes un Zemgales pilīm (228-264). Rīga: Latvijas Vēstures institūta apgāds.

Grēvina, A. (1936). Viduslaiku pils. In Jaunais Zinātnieks Nr. 45. Rīga: Valtera un Rapas akciju sabiedrības apgāds.

Guerquin, B. (1984). Zamki w Polsce. Warszawa: Arkady.

Herrmann, C. (2007). Mittelalterliche Architektur im Preussenland: Untersuchungen zur Frage der Kunstlandschaft und -geographie. Petersberg: Michael Imhof Verlag.

Kajzer, L., Kołodziejski, S., \& Salm J. (2001) Leksykon zamków w Polsce. Warszawa: Wydawnictwo Arkady. 
Ozola, 2020. The Forming of Castellum-Type Castles and Four-Unit Building Complexes with Chapels in Secular Power Centres of Courland and the State of the Teutonic Order

Karlsons, Ž. (1936). Ordeņa laikmets Latvijā. In Jaunais Zinātnieks Nr. 46. Rīga: Valtera un Rapas akciju sabiedrības apgāds.

Kranz-Domasłowska, L. (2013). Double cities in the Teutonic state on the example of Torun. In RIHA Journal 0068, 8 March.

Kaune, N. (1936). Vecā Jelgava. In Jaunais Zinātnieks Nr. 62. Rīga: Valtera un Rapas akciju sabiedrības apgāds.

Lancmanis, I. (2010). Jaunatklājumi par veco pili un Jelgavas panorāma ap 1700. gadu. In Senā Jelgava. Rīga: Neputns, 72-100.

Livonijas pil̦u attêli no marķiza Pauluči albuma = Abbildungen der Livländischen Burgen im Album des Marquis Paulucci. (2008). Rīga: Latvijas vēstures institūta apgāds.

von Löwis of Menar, K. (1922). Burgenlexikon für Alt-Livland. Riga: Walters und Rapa.

Lūsēns, M. (2002). Ventspils Livonijas ordeņa pils apbūve 13.-16. gadsimtā. Ventspils Muzeja Raksti, II grāmata, 172-182.

Meinarte, A. (2002). Kurzemes pilis un pilsdrupas Hermaṇa Frīdriha Vēbera (1761-1833) zīmējumos un akvareḷos. In Latvijas viduslaiku pilis, III. Pētījumi par ordeṇpilīm Latvijā (389-408). Rīga: Latvijas vēstures institūta apgāds.

Meißner, C. (1917). Das schöne Kurland. Ein deutsches Land. München: Piper \& Co Verlag.

Milicers, K. (2009). Vācu ordeña vēsture. Rīga: Zvaigzne ABC.

Milicers, K. (1994). Bruṇinieki Vācu ordeņa Livonijas atzarā: 1237-1562. Latvijas vēstures institūta žurnāls, Nr. 3, 47-55.

Moretti, D. (1831). Plan of San Marco Square in Venice. Quadri, A. (1987) Il Canal grande di Venezia. Venice: Vianello Libri.

Neumann, W. (1887). Grundriss einer Geschichte der bildenden Kunste in Liv-, Est- und Kurland vom Ende des 12. bis zum Ausgang des 18. Jahrhunderts. Reval: Verlag von Franz Kluge.

Ose, I. (2001). Latvijas viduslaiku pilis, II. Latvijas viduslaiku pil̨u pētniecība 18. - 20. gadsimtā. Rīga: Latvijas vēstures institūta apgāds.

Ose, I. (2011). Kapelas un baznīcas Latvijas viduslaiku pilīs. Latvijas viduslaiku pilis, VII. Pètījumi un avoti par Livonijas ordeṇpilìm (95-144). Rīga: Latvijas Universitātes Latvijas vēstures institūts.

Ozola, S. (2013). Pilsētu un administratīvi politisko centru plānojums un apbūve Rietumlatvijas teritorijā no 13. līdz 16. gadsimtam. Latvijas Zinātņu Akadèmijas Vēstis, A dal̦a, 67. sējums, 4-22.

Ozola, S. (2018a). The Impact of Catholic Monastery Church Building on Cistercian Monastery Formation in Livonia and the State of the Teutonic Order during $13^{\text {th }}$ and $14^{\text {th }}$ Century. Landscape Architecture and Art, Volume 12, 23-43. DOI: 10.22616/j.landarchart. 2018.12.07

Ozola, S. (2018b). The Tower House - the Strategically Significant Component of Power Centres' Fortified Building Complexes in Livonia and in the Tuetonic Order State during the $13^{\text {th }}-14^{\text {th }}$ Centuries. Proceedings of the $60^{\text {th }}$ International Scientific Conference of Daugavpils University. Part C Humanities, 166-198.

Pistohlkors, G. (1994). Deutsche Geschichte in Osten Europas: Baltische Länder, Volume 4. Berlin: Siedler Verlag.

Radetzky, J. (1841). Denkmaler aus der Vorzeit Liv, Ehst und Kurlands. In Ein Beitrag zur Geschichte der Ritterburgen und Kloster der Ostsee-Provinzen, (140-149). Riga.

Schlippenbach, von U.F. (1809). Malerische Wanderungen durch Kurland. Riga, Leipzig: C.J.G. Hartmann. 
Proceedings of the International Scientific Conference. Volume V, May $22^{\text {th }}-23^{\text {th }}$, 2020. 752-774

Schmid, B. (1921). Die Burgen des Deutschen Ritterordens in Kurland. In Zeitschrift für Bauwesen, (199-238). Heft 7-9. Berlin: Wilhelm Ernst \& Sohn.

Schmid, B. (1938). Die Burgen des Deutschen Ritterordens in Preussen. Berlin: Verwaltung der Staatlichen Schlösser und Gärten.

Spārītis, O. (1995). Vācbaltiešu kultūras vērtības Kurzemē. In Kurzeme un kurzemnieki (84-94). Rīga: Latvijas enciklopēdija.

Spekke, A. (2008). Latvijas vēsture. Rīga: Jumava.

Steinbrecht, C. (1888). Die Baukunst des Deutschen Ritterordens in Preußen. Band 2: Preussen zur Zeit der Landmeister. Berlin: Verlag von Julius Springer.

Steinbrecht, C. (1910). Die Baukunst des Deutschen Ritterordens in Preußen. Band 3: Schloss Lochstedt und seine Malereien. Berlin Verlag von Julius Springer.

Šterns, I. (2002). Latvijas vēsture. 1180-1290: Krustakari. Rīga: Latvijas vēstures institūta apgāds.

Šterns, I. (1997). Latvijas vēsture. 1290-1500. Rīga: Daugava.

Torbus, T. (2016). The Architecture of the Castles in the Prussian State of the Teutonic Order. In Archaeology and Architecture of the Military Orders. New Studies (219-249). London, New York: Routledge, Taylor \& Francis Group.

Torbus, T. (1998). Die Konventsburgen im Deutschordensland Preussen. München: Oklenbourg. DOI.org/10.11588/diglit.43361\#0645

Tumler, M. (1954). Der Deutsche Orden im Werden, Wachsen und Wirken bis 1400 mit einem Abriß der Geschichte des Ordens von 1400 bis zur neuesten Zeit. Wien: Panorama Verlag.

Turnbull, S. (2004). Crusader Castles of the Teutonic Knights, Volume 2: The stone castles of Latvia and Estonia 1185-1560. Oxford: Osprey Publishing.

Turnbull, S. (2011). Crusader Castles of the Teutonic Knights. Volume 1: The red-brick castles of Prussia 1230-1466. Oxford: Osprey Publishing.

Tuulse, A. (1942). Die Burgen in Estland und Lettland. Dorpat: Dorpater Estnischer verlag.

Vartberges Hermaña Livonijas hronika. (2005). Rīga: Latvijas vēstures institūta apgāds.

Vasiljev, J.M. (1986). Latvija. Istoricheskij ocherk. In Pamjatniki iskusstva Sovetskogo Sojuza: Belorussija, Litva, Latvija, Estonija. Spravochnik - putevoditel. Moskva, Leipzig: Izdatelstvo Iskusstvo, VEB Interdruck Leipzig, XL-LVI.

Voigt, J. (1843). Namen - Codex der deutschen Ordens-Beamten, Hochmeister, Landmeister, Großgebietiger, Komthure, Pfleger, Hochmeister-Kompane, Kreuzfahrer und SöldnerHauptleute in Preussen. Koenigsberg: Bornträger.

Voigt, J. (1857-1859). Geschichte des Deutschen Ritterordens. Berlin: Reimer.

Voigt, J. (1842-1843). Handbuch der Geschichte Preußens bis zur Reformation. Königsberg: Bornträger.

Voigt, J. (1827-1839). Geschichte Preußens von den ältesten Zeiten bis zum Untergange der Herrschaft des Deutschen Ordens. Königsberg: Bornträger.

Wünsch, C. (1960). Ostpreussen. München: Deutscher Kunstverlag.

Zemītis, G. (2005). Arheologiskās liecības par Jelgavas pili Kurzemes hercogu Ketleru dinastijas laikā. In Latvijas viduslaiku pilis, V. Pêtījumi par Kurzemes un Zemgales pilìm (185-204). Rīga: Latvijas vēstures institūta apgāds. 